九州大学学術情報リポジトリ

Kyushu University Institutional Repository

\title{
Buddhist Texts on Gold and Other Metals in East Asia : Preliminary Observations
}

Kornicki, Peter

Cambridge University : Emeritus Professor of Japanese

Barrett, T. H.

Department of Religions and Philosophies, SOAS : Emeritus Professor

https://doi.org/10.5109/1806142

出版情報: Journal of Asian Humanities at Kyushu University. 2, pp.111-124, 2017-03. Kyushu University, School of Letters, Graduate School of Humanities, Faculty of Humanities バージョン:

権利関係 : 


\title{
Buddhist Texts on Gold and Other Metals in East Asia: Preliminary Observations
}

\author{
PETER KORNICKI WITH T. H. BARRETT
}

F printing is defined as a means of producing multiple copies of a given text, then the cylinder seals used from the second millennium в СE onward by the Akkadians and other peoples in the ancient Middle East have a claim to be considered as the earliest attempts to print in the world. ${ }^{1}$ Further to the east, in northern India, short Buddhist texts, either the so-called Buddhist creed or dhäraṇi invocations, were repeatedly stamped into soft clay at least by the second century вCE, and this practice spread to Afghanistan, Southeast Asia, Central Asia, and Tibet. ${ }^{2}$ While stamped clay tab-

We are grateful to the anonymous British collector who has allowed images from items in his possession to be used in this article and to the anonymous referees whose constructive comments enabled us to make considerable improvements to this article.

1 Dominique Collon, First Impressions: Cylinder Seals in the Ancient Near East (London: British Museum, 1987).

2 Simon D. Lawson, "A Catalogue of Indian Buddhist Clay Sealings in British Museums," (D.Phil. diss., University of Oxford, 1982); Arlo Griffiths and D. Christian Lammerts, "Epigraphy: Southeast Asia," in Brill's Encyclopedia of Buddhism, ed. Jonathan A. Silk, vol. 1 (Leiden: Brill, 2015), 988-1009; Jeremiah P. Losty, The Art of the Book in India (London: British Library, 1982); and B. A. Litvinskii and T. I. Zeimal', "Nekotorye aspekty ierarkhii i semantiki stūpa b srednei Azii i Indii," in Drevniaia Indiia: istoriko-kul'turnye sviazy, ed. G. M. Bongard-Levin (Moscow: Nauka, 1982), 183-4. lets were undoubtedly thus a form of printing, this was undertaken in order to reproduce multiple copies of short Buddhist texts for votive or ritual purposes rather than for reading. It was a response to instructions given in certain sutras that promised long life or other benefits if texts were multiplied a prescribed number of times. Once the copies of the text had been produced, they were usually placed inside a stupa or pagoda and then served no further purpose: in other words, it was the act of production and their installation inside a stupa that was the point, rather than what subsequently happened to them.

That, on the face of it, is the nearest we get to printing until the eighth century, when multiple copies of texts were being reproduced on paper in China, Korea, and Japan, albeit still for ritual purposes rather than for reading. These, too, were subsequently placed inside miniature pagodas or larger pagodas and served no further purpose. ${ }^{3}$ It should be noted that these various technologies for the multiplication of texts do not pro-

3 Peter Kornicki, "The Hyakumantō Darani and the Origins of Printing in Eighth-Century Japan," International Journal of Asian Studies 9 (2012): 1-28. 
duce absolutely identical copies owing to the wear and tear suffered by the seals, stamps, or wooden blocks, but the copies are textually identical. This is, of course, not necessarily the case with texts multiplied by hand, which are prone to dittography, haplography, and other forms of inadvertent error. These technologies can, therefore, be seen as early forms of printing.

In this article we examine some Buddhist texts on metal plates produced in East Asia that show signs of having been produced by means of a different ancient form of printing. Some of these metal plates have never been properly studied and others are, for various reasons, inaccessible and all that is currently available for research is an image. What links them is the fact that all reproduce parts of the Chinese Buddhist canon in metal. The use of a precious metal as a medium was not unique to East Asia, since metal plates were used in South and Southeast Asia for both Buddhist texts and administrative documents. The East Asian examples are, for the most part, much less known, and in some cases not known at all, but it is clear that this practice reached China, Japan, Korea, and the Khitan (Liao) empire and deserves to be better known.

These metal plates carrying texts need to be considered in the context both of the functions of material texts in Buddhism and of the materiality of writing in East Asia. As mentioned, the discovery of stamped clay tablets in Afghanistan, Southeast Asia, Central Asia, and Tibet reveals that the material forms of Buddhist texts were not necessarily designed to preserve or disseminate those texts even when produced in multiple copies, and the same was true later of Buddhist texts printed on paper. The clay tablets were in fact an essential part of devotional practices prescribed particularly in dhäraṇi sutras, which contain the texts of Buddhist spells or invocations known as dhäranī. The dhärani were either to be recited orally a number of times or reproduced in one of a number of specified ways, including copying by hand. ${ }^{4}$ When reproduced on clay or some other semi-permanent material, the texts were

4 Richard D. McBride, "Dhāraṇī and Spells in Medieval Sinitic Buddhism," Journal of the International Association of Buddhist Studies 28 (2005): 85-114; Yael Bentor, "On the Indian Origins of the Tibetan Practice of Depositing Relics and Dhâranîs in Stūpas and Images," Journal of the American Oriental Society 115 (1995): 248-61: and Paul Copp, "Altar, Amulet, Icon: Transformations in Dhāraṇi Amulet Culture, 740-980," Cahiers d'Extrême-Asie 17 (2008): $239-64$ placed inside a caitya, stupa, or pagoda. ${ }^{5}$ These practices were witnessed by two Chinese monks who visited India in the seventh century, Xuanzang 玄焋 (c. 602-64) and Yi Jing 義淨 (635-713):

It is a custom in India to make little stūpas of powdered scent made into a paste; their height is about six or seven inches, and they place inside them some written extract from a sūtra. ${ }^{6}$

[People in India] make [incense] paste caityas and paste images from rubbings. Some impress them on silk or paper, and venerate them wherever they go. Some amass them into a pile, and by covering them with tiles, they build Buddha-stūpas.... Furthermore, whether they build images or make caityas, be they of gold, silver, bronze, iron, paste, lacquer, brick or stone, or they heap up sand like snow $[$ sic], when they make them, they place inside two kinds of relics. One is called the bodily relic of the Great Teacher; the second is called the dharma-verse relic on causation. ${ }^{7}$

In light of these accounts, it seems that the material texts, whether printed on paper, hammered or inscribed in metal, or molded or stamped in clay, or otherwise produced and placed inside stupas are best considered not as 'books' but as 'written embodiments of Buddhahood,' in other words, as a replacement for the bodily relics that had earlier been placed inside stupas. ${ }^{8}$ This is a somewhat different concept from that

5 Stupa denotes a Buddhist monument, while a caitya was a funerary monument, but in Buddhist contexts they are often used indiscriminately. The word pagoda, which is of uncertain etymology, is used mainly to refer to the form the stupa took in East Asia when made of timber, brick, or stone.

6 Samuel Beal, Si-yu-ki, Buddhist Records of the Western World 2 vols. (London: Kegan Paul, Trench, Trübner \& Co., 1906), 2.146; T 51, \#2087, 920a; T51n2087_po920a21-23 (henceforth to be recognized as CBETA digitized canon).

7 Junjiro Takakusu, A Record of the Buddhist Religion as Practised in India and the Malay Archipelago (A.D. 671-695) (Oxford: Clarendon Press, 1896), 150; T54n2125_po226c15-2O. On the references to "sand like snow" and paper, see T. H. Barrett, "Did I-Ching Go to India? Problems in Using I-Ching as a Source on South Asian Buddhism," Buddhist Studies Review 15 (1998): 142-56.

8 James B. Apple, "The Phrase Dharmaparyāyo Hastagato in Mahāyāna Buddhist Literature: Rethinking the Cult of the Book in Middle Period Indian Mahāyāna Buddhism," Journal of the American Oriental Society 134 (2014): 26. See also the articles cited in note 4 , above. 
of the 'cult of the book,' the notion that texts in the material form of books can themselves become objects of worship, which has been much discussed in the context of Mahāyāna Buddhism in India and further afield. ${ }^{9}$

With regard to the second point, the materiality of texts in East Asia, it is important to remember that in early China non-Buddhist texts were inscribed on various surfaces, including tortoise shells and ox scapulae used for oracle bone inscriptions, and pieces of jade in the case of Daoist inscriptions. Metal was used in the case of cast-bronze vessels, which sometimes carried inscriptions as part of the casting and which date from ca. 1200 BCE onward. ${ }^{10}$ The casting technique was at least theoretically capable of producing multiple copies, but the texts in such cases are epiphenomenal: that is to say, the point seems to have been to produce the bronze vessel, which subsequently was used in rituals or placed in a grave and may or may not have included a text, rather than to present a text, which was a secondary consideration. ${ }^{11}$ By contrast, the Buddhist texts to be discussed below are not epiphenomenal: the sole or main purpose of the plates made of gold and other metals was to act as a medium for the text. And so far, the only such metal plates found in East Asia carry Buddhist texts. In South Asia and Southeast Asia, on the other hand, they were used for other purposes as well: copper was used extensively to record land transactions; other metals, including precious metals, were sometimes used to record dedications or the details of ritual acts. The use of metal in these circumstances was presumably in the interest of preservation. ${ }^{12}$

9 See Apple, "The Phrase Dharmaparyāyo Hastagato in Mahāyāna Buddhist Literature;" and David Drewes, "Revisiting the Phrase

'Saprthivippradeśaś Caityabhūto Bhavet' and the Mahāyāna Cult of the Book," Indo-Iranian Journal 50 (2007): 101-43

10 Gil Raz, The Emergence of Daoism: Creation of a Tradition (Abingdon: Routledge, 2012), 164-5; Stephen R. Bokenkamp, Early Daoist Scriptures (Berkeley: University of California Press, 1997), 313; and Lothar Ledderose, Ten Thousand Things: Module and Mass Production in Chinese Art (Princeton, NJ: Princeton University Press, 2000), 40-4, 153-7.

11 Chengyuan $\mathrm{Ma}$, "The Splendor of Ancient Chinese Bronzes," in The Great Bronze Age of China: An Exhibition from the People's Republic of China, ed. Wen Fong (New York: The Metropolitan Museum of Art, 1980), 10, 15.

12 Arlo Griffiths, "New Documents for the Early History of Pundravardhana: Copperplate Inscriptions from the Late Gupta and Early Post-Gupta Periods," Pratna samiksha 6 (2015): 15-38; Arlo Griffiths and D. Christian Lammerts, "Epigraphy: Southeast Asia," in Brill's Encyclopedia of Buddhism, ed. Jonathan A. Silk, vol. 1 (Leiden: Brill, 2015), 991 and passim; and Richard Salomon, Indian Epigraphy: A Guide to the Study of Inscriptions in Sanskrit,
In the case of Buddhist texts, it is already well known that some metals, including gold, were used for the production of single copies of Buddhist texts in South Asia. As Losty has pointed out, "from a very early period are found votive offerings on gold or silver inscribed with the Buddhist creed, which would appear to have been placed in stuppas or buried in the foundations of monasteries or similar religious foundations." ${ }^{\prime 3}$ The use of gold and other metals, the evidence suggests, gradually spread to other parts of the Buddhist ecumene. At Anuradhapura in Sri Lanka, seven gold plates containing portions of the Prajñāpāramitā sūtra inscribed in Sanskrit in Sinhala script were found in $1982 .{ }^{14} \mathrm{Sim}$ ilarly, in 1897 two gold plates inscribed in Pali were found in Burma near Śrī Kșetra (modern Hmawza), one of the Pyu city states; known as the Maunggan gold plates, they are now in the British Library and probably date from the sixth century. ${ }^{15}$ The National Museum of Myanmar in Yangon also has three gold leaves inscribed in Pali that were found in the Khin Ba stupa mound in Śrī Kșetra in 1926-27, which are ascribed to the fifth century CE. ${ }^{16}$ Farther to the southeast, in what is now Indonesia, a number of Buddhist texts, including dhārānīi, inscribed on gold, silver, or lead foil have been found, and they are thought to date from around the ninth century $\mathrm{CE} .{ }^{17}$

Prakrit, and the Other Indo-Aryan Languages (Oxford: Oxford University Press, 1998), 122-3, 129-30.

13 Losty, The Art of the Book in India, 10.

14 John Clifford Holt, Buddha in the Crown: Avalokiteśvara in the Buddhist Traditions of Sri Lanka (Oxford: Oxford University Press, 1991), 67: Hema Ratnayaka, M. H. Sirisoma and Siri Heenpella, Jetavanārāma Gold Plates (Colombo: Ministry of Cultural Affairs, 1983); and M. H. F. Jayasuriya, The Jetavanārāma Gold Plates: Being a Fragmentary Sri Lankan Recension of the Pañcavimśatisāhasrikā Prajñāpāramitā Sūtra ([Kelaniya]: University of Kelaniya, [1988]).

15 Griffiths and Lammerts, "Epigraphy," 996; and Harry Falk, "Die Goldblätter aus Śrī Ksetra," Wiener Zeitschrift für die Kunde Südasiens 41 (1997): 53-92.

16 Janice Stargardt, "The Oldest Known Pali Texts, 5th-6th Century; Results of the Cambridge Symposium on the Pyu Golden Pali Text from Śrī Kṣetra, 18-19 April 1995," Journal of the Pali Text Society 21 (1995): 199-213; and Falk, "Die Goldblätter." They are illustrated in Thein Lwin, Win Kyaing, and Janice Stargardt, "The Pyu Civilization of Myanmar and the City of Śrī Kșetra," in Lost Kingdoms: Hindu-Buddhist Sculpture of Early Southeast Asia, ed. John Guy (New York: Metropolitan Museum of Art, 2014), 65

17 Arlo Griffiths, "Early Indic Inscriptions of Southeast Asia," in Lost Kingdoms: Hindu-Buddhist Sculpture of Early Southeast Asia, ed. John Guy (New York: Metropolitan Museum of Art, 2014), 53-7; Arlo Griffiths, "The 'Greatly Ferocious' Spell (Mahāraudra-nāma-hṛdaya). A Dhāraṇi Inscribed on a Lead-Bronze Foi Unearthed near Borobudur," in Epigraphic Evidence in the 
The production of such texts as these, inscribed on gold or gilt plates or other metals, certainly has scriptural authority in the Mahāyāna tradition. One example is to be found in the Perfection of Wisdom in 8,ooo Lines (Sk. Aștasahasrikā Prajñāpāramitā), which was translated into Chinese on several occasions, the first time in the second century CE (Bachansong banruo jing 八千 頌般若経). ${ }^{18}$ Knowledge of these votive practices may well have been transmitted to China orally by the many Chinese and Korean travelers to India or by monks from India, Sri Lanka, and Central Asia who travelled to China, but they were also embodied both in texts written by Chinese travelers themselves describing what they had seen and in scriptures that mentioned such practices. ${ }^{19}$ For example, a text translated into Chinese in the early fifth century states that Ashoka had Buddhist texts inscribed on gold in order to preserve them. ${ }^{20}$ This reference alone would at least have introduced the practice of inscribing Buddhist texts on gold to readers of the Chinese Buddhist canon all over East Asia. Furthermore, the dominant school of Buddhism in Sri Lanka was known in China as the 'school of red copper plates' (chi tongye bu 赤銅鍱部), and the Chinese pilgrim Xuanzang recorded a story that in the time of the Buddhist King Kanishka the canon was preserved on copper leaves. ${ }^{21}$ The practice of inscribing Buddhist texts on gold is also mentioned in a Chinese translation of the early eleventh century, a time when there were increased Chinese contacts with maritime South

Pre-Modern Buddhist World, ed. Kurt Tropper (Vienna: Arbeitskreis für Tibetische und Buddhistische Studien, Universität Wien 2014), 1-36; and Arlo Griffiths, "Written Traces of the Buddhist Past: Mantras and Dhāraṇīs in Indonesian inscriptions," Bulletin of the School of Oriental and African Studies 77 (2014): 137-94.

18 Will Tuladhar-Douglas, "Writing and the Rise of Mahāyāna Buddhism," in Die Textualisierung der Religion, ed. Joachim Schaper (Tübingen: Mohr Siebeck, 2009), 255-7; and Seishi Karashima, A Critical Edition of Lokakșema's Translation of the Astasāhasrikā Prajñāpāramitā 道行般若經校注 (Tokyo: The International Research Institute for Advanced Buddhology, Soka University, 2011) 495

19 Tim Barrett, The Woman Who Discovered Printing (New Haven: Yale University Press, 2008), 102-3.

20 Foshuo pusa xing fangbian jingjie shentong bianhua jing 佛 説菩薩行方便境界神通變化經 (translated by the Indian monk Gunabhadra 求那跋陀羅, 394-468), To9no271_p0315c29O316ao1.

21 Chuan Cheng, "Designations of Ancient Sri Lankan Buddhism in the Chinese Tripitaka," Journal of the Oxford Centre for Buddhist Studies 2 (2012): n. 13 and passim. and Southeast Asia. ${ }^{22}$ Consequently, although the Fozu tongji 佛祖統紀 (General Records of the Founders of Buddhism) was compiled in the thirteenth century, it is intrinsically credible in asserting that a Chola mission arrived in China in 1023 with texts in Sanskrit on gold leaf, and that Dharmapāla, the translator of one of the texts we now have printed on gold, was instructed to translate these materials. ${ }^{23}$

In light of all this, it seems that there can be little doubt that Buddhist texts on gold leaf were familiar in China at least as a concept, and were most likely seen and produced there. What is more, the textual references must have made the practice known in neighboring societies that acquired copies of the texts contained in the Chinese Buddhist canon.

In addition to all these textual references, there is now considerable concrete evidence for the spread to East Asia of the practice of producing Buddhist texts on gold or other metals, as the following examples show. These examples are, however, very uneven in terms of the amount of information currently available. Each will be discussed separately, and then some consideration will be given to the points they have in common, to the extent that current knowledge makes this possible.

1. In northeastern China restoration work at the socalled White Pagoda (Shijiafo Sheli Pagoda 釈迦仏 舎利塔) in Balin Right Banner, Inner Mongolia, has brought to light several items of interest. The White $\mathrm{Pa}$ goda was built in 1047, when that area of China was part of the Khitan empire, and it was at that time that some items were placed in a relic depository at the base of the pagoda. In 1049 a further depository was constructed in the pinnacle of the pagoda, and this contained three gilt sutras. ${ }^{24}$ Unfortunately, the full details of these have not yet been made available. However, the first of the sutras is a small silver sheet (11.6 x 21.2; measurements given in centimetres with vertical measurement given first) with a text inscribed in intaglio, and it is a text that

\footnotetext{
22 Foshuo wunengsheng damingwang tuoluonijing 佛説無能勝大明 王陀羅尼經, T21n1233_po173bo3.

23 Fozu tongji 佛祖統紀 45, T49n2O35_po408co2-O4.

24 Hsueh-man Shen, ed., Gilded Splendor: Treasures of China's Liao Empire (907-1125) (New York: Asia Society, 2006), 74, 82-83; and Youn-mi Kim, "The Hidden Link: Tracing Liao Buddhism in Shingon Ritual," Journal of Song-Yuan Studies 43 (2013): 151-52.
} 
had already been used in both Korea and Japan as part of a ritual practice intended to prolong life. The text is a passage from the Chinese translation of the Sutra of the Dhārānī of Pure Unsullied Light (Sk. Raśmivimalaviśuddhaprabhādhārañi sūtra, Ch. Wugou jingguang ta tuoluoni jing 無垢浄光大陀羅尼經), which was translated into Chinese by a Tokharian monk called Mitraśānta 彌陀山 (fl. late $7^{\text {th }}$-early $8^{\text {th }} \mathrm{c}$.), together with Fazang 法藏 (643-712), in the 'last years' of the reign of empress Wu 武則天 (r. 690-705). ${ }^{25}$ Another object is a gilt-silver sheet ( $9.0 \times 102.5 ; 0.05$ thick) containing the text of the Sutra of the Dhārānī of Pure Unsullied Light. There is also a gold sheet with the Sanskrit text of Xiangluntang zhong tuoloni zhou 相輪樘中陀羅尼 呪, one of the dhārānī from the Sutra of the Dhärānī of Pure Unsullied Light. ${ }^{26}$

2. The large North Pagoda in Chaoyang city, Liaoning province, has also yielded metal sutras. The North $\mathrm{Pa}$ goda seems to have originally been constructed during the Tang dynasty (618-907) and then enlarged in the mid-eleventh century, when this part of southern Manchuria was part of the Khitan empire. Restoration work carried out in the 1980s revealed the existence of two cavities, one underground and another at the top of the pagoda. The cavity at the top contained, among other things, a standing silver-gilt sutra container dated the twelfth year of Chongxi 重熙 (1043). Inside this was found a roll formed of seven sheets of silver fixed together to form one long sheet $(11.3 \times 362.2)$ with a text entitled Banruo boluomiduo xin jingboluomiduo jing 波 羅密多心經, i.e, the Heart Sutra (Sk. Prajñāpāramitā hrdaya sūtra), along with three dhārānī in Chinese and Sanskrit, although it is not stated if these are also on silver-gilt sheets. No further details and no illustrations are provided. ${ }^{27}$

3. In 1965 excavations at the Wangungri site in Iksan in southwestern Korea led to the discovery in the stone five-storey pagoda of nineteen gold plates (14.8 x 17.4) containing the inscribed text of part of the Diamond

\footnotetext{
25 Kornicki, "The Hyakumantō Darani," 50-1.

26 Shen, Gilded Splendor, 244-45, 250; and Neimenggu Balin youqi bowuguan,"Liaodai shijia fo shelita nei chutu de Wugou jingguang ta tuoluoni jing liu jin yin ban," Beifang wenwu 69 (2002.1): 52-3. Unfortunately, this very brief article consists mostly of a transcription of the text and provides very few other details.

27 Dong Gao and Zhang Hongbo, "Liaoning Chaoyang beita tiangong digong qingli jianbao," Wenwu 434 (1992.7): 6.
}

Sutra (Sk. Vajracchedikā Prajñāpāramitā sūtra, Ch. Foshuo jingang banruo boluomiduo jing 仏説金剛般若波 羅密多經) in the translation by Kumārajīva (334-413) completed in the early fifth century. The date of construction of the pagoda is uncertain, but Song Ilgi, the author of the only detailed report, has assigned the gold plates to the seventh century on the basis of the written forms of the characters and the variant characters used in the text. ${ }^{28}$

Some light is cast on this find by a twelfth-century Japanese manuscript copy of a collection of Buddhist folk tales titled Guanshiyin yingyan ji 觀世音應驗記 (Responsive Manifestations of Avalokiteśvara), which is preserved in the Shōren'in 青蓮院 temple in Kyoto. The manuscript includes at the end a passage concerning King Mu 武 (r. 600-40) of Paekche. This passage, which seems to have been included in the original manuscript of which this is a copy, states that in the tenth year of the Tang-dynasty Zhenguan 貞觀 era (639), the Chesŏksa 帝釋寺 temple at Iksan was consumed by fire, but that the pagoda was found to contain, amongst other Buddhist relics, "copper plates which had been used as paper on which to copy the Diamond Sutra." 29 The specificity of detail in this passage is impressive, but the original source from which it was taken is not specified in the manuscript and the claim cannot be corroborated by any extant sources. Leaving aside those difficulties, it appears from this passage that the Chesŏksa copper plates it refers to had been made some considerable time before the year 639. What connection they have with the recently discovered gold plates is unclear. Were they damaged in the fire and therefore remade using gold instead of copper?

4. Another Korean example is the Thousand-arm Sutra, which appears to have been inscribed on sixteen gold (or gold-plated) plates (11.1 x 12.8) held together by hinges. The first plate gives the title Qianshoujing 千 手經 (possibly an abbreviation of Qianshou qianyan

28 Song llgi, "Iksan Wanggungt'ap Kŭmji kŭmgang sagyŏng ŭi munhŏnhakjŏk chŏpkŭn," Sŏjihak yŏngu 24 (2002): 131-59. The gold sheets were on display at the "Cultural Relics of Iksan" exhibition from 28 October 2015 at the new Chŏnju National Museum; for images see http://www.korea.net/NewsFocus/Culture/view?articleld=114304 (accessed 5 January 2017).

29 Makita Tairyō, Rikuchō koitsu Kanzeon ōgenki no kenkyū (Kyoto: Heirakuji Shoten, 1970), 4-6, 60; and Song Ilgi, "Kyŏngdo Ch'ŏngnyŏnwŏn chang Kwanseŭm ŭnghŏmgi sosu Paekche kisa ŭi kyŏndo," Sŏjihak yŏngu 30 (2005): 129-49. 
guanshiyin pusa guangda yuanman wuai dabeixin tuoloni jing 千手千眼觀世音菩薩廣大圓滿無礙大悲心 陀羅尼經). However, the text does not appear to coincide with any of the extant seven translations, so it is not possible to provide a terminus ante quem. The only published account of this sutra on gold plates provides illustrations but no information about when or where it was found, although it is said to have been "treasured by a Buddhist believer" for a long time and only recently made available for study, which suggests that it is in a private collection. The author of this account assigns it to some time before the middle of the Koryŏ dynasty (918-1392) on calligraphic grounds. ${ }^{30}$

5. The Zentner Collection, an Asian antiques dealer in Emeryville, California, recently had for sale on its website what was said to be a Korean gilt reliquary with a gilt-metal sutra. The latter is described as follows: "flat rectangular gilt metal section with raised characters of Buddhist text and praying figure on the left, the other side of the display has a similar rectangular section of raised Buddhist text and two figures on silver, dates to about 11th to $13^{\text {th }}$ century." ${ }^{11}$ The grounds for assigning the gilt sutra to Korea and to the Koryŏ dynasty are not provided, but the visible text is the Heart Sutra in the Chinese translation by Xuanzang. Unlike many other examples, these characters are said to be in relief, probably using the repoussé technique.

6. In Japan a number of sutras on copper have been found, the oldest of which is a plate $(83.3 \times 75.0)$ from Hasedera 長谷寺 temple in Nara prefecture that contains an image and twenty-seven lines of inscribed text from the Lotus Sutra and dates from the seventh century. ${ }^{32}$ A great many others date from the Heian period (794-1185), including the thirty-three copper plates (21.0 x 18.0) inscribed on both sides with the Lotus Sutra and Sutra of the Heart of

30 Yi Chaejun, "Kŭmje Ch’ŏnsugyŏng e kwanhan sogo," Munhwasahak 21 (2004): 519-36.

31 The item has been sold according to the company's website. Images and description are posted there: http://www.zentnercollection.com/items/1253385/Korean-Ancient-Buddhist-Gilded-Sutra-Reliquary (accessed 16 June 2016 and 2 January 2017). The author will provide screen shots of the images on request should the item be removed from the website.

32 For illustrations and a good account, see https://ja.wikipedia.org/ wiki/長谷寺銅板法華説相図 (accessed 19 June 2016). For further details, see Kataoka Naoki, "Hasedera dōban Hokke sessōzu no meibun ni tsuite: Kōtei, kaishaku chōkoku gihō," Niigata Sangyō Daigaku Keizaigakubu kiyō 40 (2012): 1-17.
Wisdom from the Kunitama 国玉 shrine at the summit of Mt. Kubote (Buzen city, Fukuoka prefecture), and the buried Lotus Sutra from Kinpusen in Nara prefecture. ${ }^{33}$ Some other examples carry dates: a single copper sheet (21.0 x 18.0; 0.2 thick) with part of the Lotus Sutra inscribed on both sides, which was found in a sutra mound at the Chōanji 長安寺 temple in Oita prefecture, is dated 1141. Another (14.3 x 36.0; 1.0 thick), found inside a miniature stone pagoda, contains the text of the Sutra of the Casket Seal (Sk. Karandamudrā-dhāran̄ī, Ch. Baoqieyin tuoluoni jing 宝筮印陀羅尼経), which was closely connected with practices involving relics. This is dated to 1773, showing that the practice continued in Japan up to the eighteenth century. ${ }^{34}$ Some if not all of the Japanese examples seem to have been prompted by the notion of the degeneration of Buddhism encapsulated in the concept of the 'Latter days of the Law' (Ch. mofa, Jp. mappō 末法), which became a widespread belief in Japan in the eleventh century, and by the concomitant desire to ensure the preservation of the Buddha's words in the form of written texts for future ages. In addition, however, inscriptions reveal that donors were simultaneously motivated by the desire for personal rebirth, either for themselves or for those in whose interest they sponsored the preparation of the sutras for burial. Particularly from the thirteenth century onward, mappō was replaced as the principal motive by a desire for personal salvation. ${ }^{35}$

33 Institut de philosophie orientale and Association culturelle Soka de France, eds., Sūtras bouddhiques: un héritage spiritual universel. Manuscrits et iconographie du Sūtra du Lotus (Paris: Les Indes savants, 2016), 142; Teishitsu Hakubutsukan, ed., Kinpusen kyōzuka ibutsu no kenkyū (Tokyo: Tōkyōdō Shuppan, 1979; facsimile of 1937 edition), 31-33, 92-94, and plates 25-29; Ishida Mosaku, "Wagakuni hakken no dōbankyō ni tsuite," Bukkyō kōkogaku ronkō, vol. 3 (Kyoto: Shibunkaku Shuppan, 1977), 377-408; Taguchi Eiichi,"Dōban Hokkekyō, tsuketaru dōbakoita," Kokka 957 (1973): 44-53; and Yajima Kyōsuke, "Kinpusen shutsudo no dōbankyō," Yamato bunka kenkyū 4, no. 3 (1957): 1-16.

34 For a fragment of a copper sutra found in Yoshino and attributed to the eleventh or twelfth century, see http://www.narahaku. go.jp/collection/493-1.html, for a Lotus Sutra inscribed in 1141 and found in Kyushu, http://bunka.nii.ac.jp/heritages/detail/214903, and for a dhārāṇi sutra inscribed on copper in 1773 found in Saitama, http://www.town.yoshimi.saitama.jp/guide_kongouin. html (all accessed 19 June 2016). On the role of the Sutra of the Casket Seal, see Norihisa Baba, "Sri Lankan Impacts on East Asian Buddhism: Transmission of a Dhāranī Sūtra," in Buddhism Without Borders: Proceedings of the International Conference on Global Buddhism, eds. Dasho Karma Ura and Dendup Chophel (Bhutan: The Centre for Bhutan Studies, 2012; http://www.bhutanstudies.org.bt/category/conference-proceedings/), 257-67.

35 Jonathan A. Silk, "Canonicity," in Brill's Encyclopedia of Buddhism, ed. Jonathan A. Silk, vol. 1 (Leiden: Brill, 2015), 29. On 


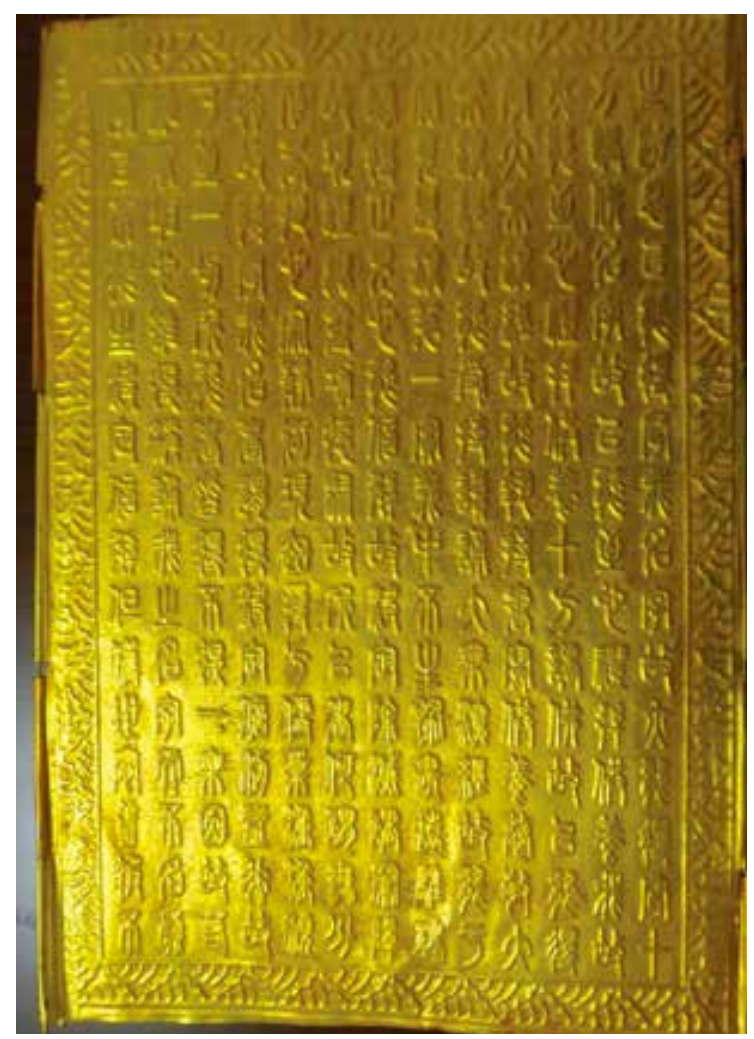

Figure 1. Sutra on the Divination of the Effect of Good and Evil Actions (Zhancha shan'e yebao jing 占察善惡業報經). H. $18.6 \mathrm{~cm}, \mathrm{w}$. $12.7 \mathrm{~cm}$. Origin and date unknown. Private collection, UK. Reproduced with permission.

It should be noted that the buried sutras found in Japan have overwhelmingly been found in sutra mounds rather than in locations associated with stupas, where relics, mirrors, and other non-textual objects are much more common. What is more, the text interred is very often, but not exclusively, the Lotus Sutra. In these respects, it is clear that Japanese practices differed from those in continental East Asia.

sutra burials in Japan, see D. Max Moerman, "The Death of the Dharma: Buddhist Sutra Burials in Early Medieval Japan," in The Death of Sacred Texts: Ritual Disposal and Renovation of Texts in World Religions, ed. Kristina Myrvold (Farnham: Ashgate, 2010), 71-90, and the literature cited therein; and Heather Blair, Real and Imagined: The Peak of Gold in Heian Japan (Cambridge, MA: Harvard University Asia Center, 2015), 175-89.

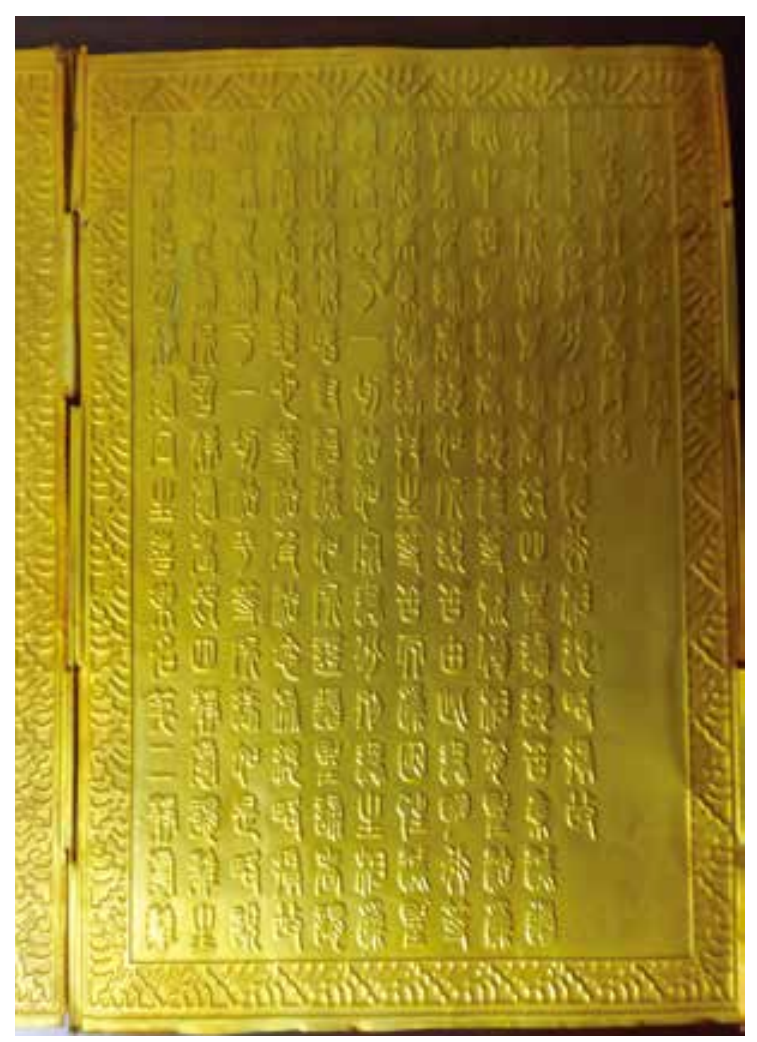

Figure 2. The beginning of the second chapter of Ji dasheng xiang lun 集大乘相論. Origin and date unknown. H. $18.6 \mathrm{~cm}, \mathrm{w} .12 .7 \mathrm{~cm}$. Private collection, UK. Reproduced with permission.

7. In addition to the above examples, which have already to some extent been individually reported and for which illustrations are mostly available, two more examples have recently come to light. They belong to a private collector in the United Kingdom who states that at the time of purchase the vendor declared that they were of Korean origin. These new examples both consist of short 'books' of seven double-sided pages (18.6 X 12.7) consisting of gilt-metal plates held together with hinges; thus each consists of fourteen plates combined in pairs to form seven 'pages.' The first book consists of part of the first chapter (beginning in the middle of a phrase) of the Sutra on the Divination of the Effect of Good and Evil Actions (Ch. Zhancha shan'e yebao jing 占察善惡業報經), which was translated into Chinese by 菩提燈 (Bodhidipa?) in the seventh century (figure 
1). ${ }^{36}$ The other consists of the second chapter of the $J i$ dasheng xiang lun 集大乘相論 (Collected Treatises on the Characteristics of the Great Vehicle), which was translated by Dānapāla 施護, a monk of the Song dynasty (960-1279), in the tenth or eleventh century (figure 2). What is unusual about these two texts is that seal script is used, for which there is so far no parallel among other Chinese Buddhist texts on metal. The other connection between these two examples is the fact that the border designs are identical; it seems, therefore, that they were produced in the same workshop and probably at the same time. Given that the Ji dasheng xiang lun was not translated until the tenth century at the earliest, this means that they were both produced after that date, during the Koryŏ dynasty if they were in fact produced in Korea.

These two texts are contained in gilt-metal boxes that clearly do not belong with them, for the titles on the lids are different from those of the contents. In the case of the second book, for example, the title on the lid is 順權方便經巻, suggesting that it originally contained a copy of the Sirivivartavyākarana sūtra (Ch. Shun quan fangbian jing 順權方便經, Sutra on Following Provisional Expedients) translated by Dharmarakșa 䇥法護 $(230 ?-316)$, and an inscription on the base of the box reads 'Da Tang Zhenguan'大 唐貞觀, suggesting that it was made in the Zhenguan era (626-649) (figures 3 and 4). Since the text actually contained in it, the Ji dasheng xiang lun, was not translated into Chinese until the tenth or eleventh century, it is obvious that the box has nothing to do with its current contents. However, if the box is what it claims to be, it may possibly be taken as evidence that Buddhist texts on metal were produced in China as early as the Tang dynasty, for the shape, which is similar to that of its present contents, suits a metal text in codex format rather than a paper roll, which in the Tang was still the usual format for Buddhist texts. There remains the possibility that the box was used to contain a paper book of the same size, for the Dunhuang Collection contains a number of paper booklets of similar size in codex, butterfly, or concertina format.

36 The text begins with the last three characters 生法忍 (T17no839_ po909a05) and thus begins in medias res. On the Sutra on the Divination of the Effect of Good and Evil Actions, see Whalen Lai, "The Chan-ch'a ching: Religion and Magic in Medieval China," in Chinese Buddhist Apocrypha, ed. Robert Buswell (Honolulu: University of Hawai'i Press, 1990), 175-206.
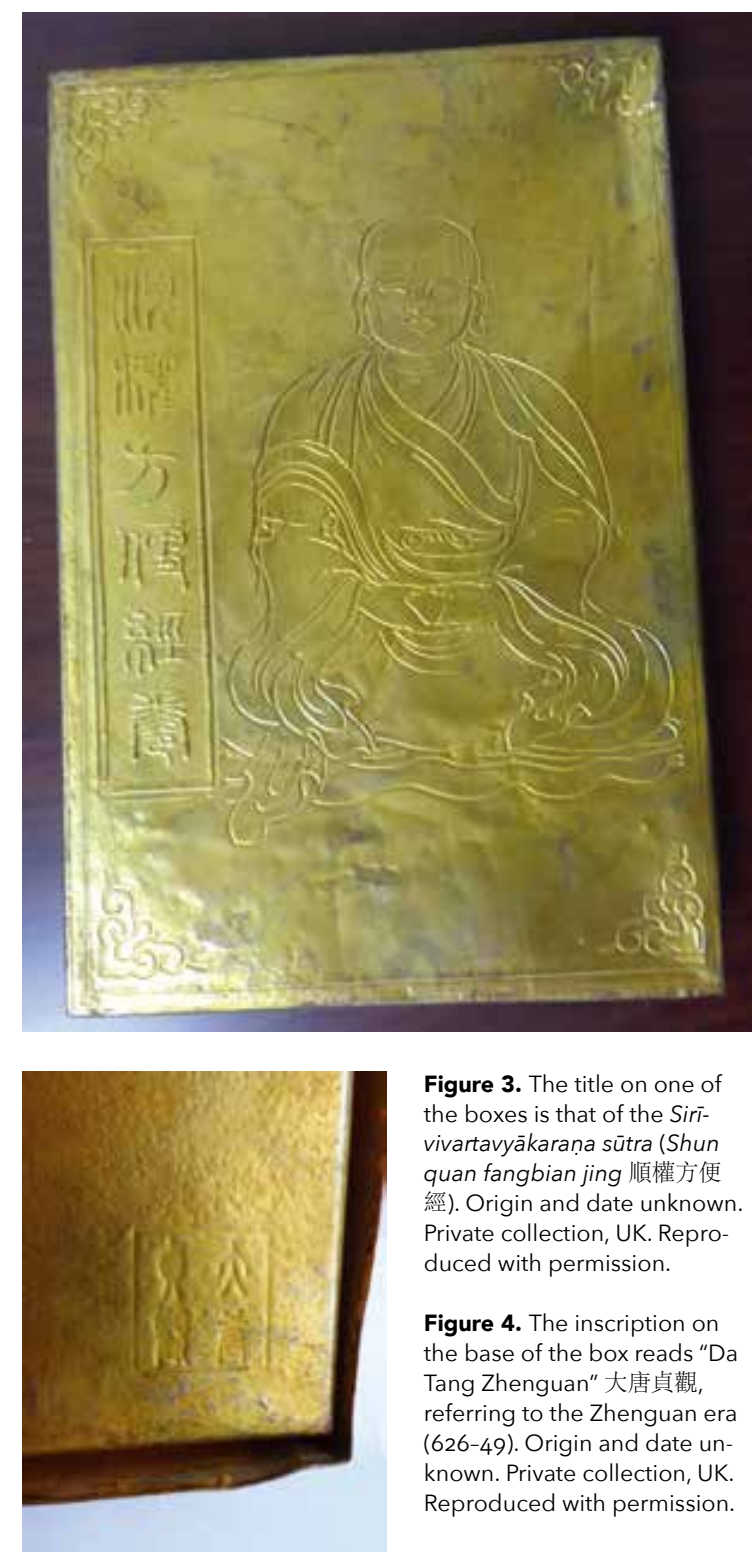

Figure 3. The title on one of the boxes is that of the Sirivivartavyākaraṇa sūtra (Shun quan fangbian jing 順權方便 經). Origin and date unknown. Private collection, UK. Reproduced with permission.

Figure 4. The inscription on the base of the box reads " $\mathrm{Da}$ Tang Zhenguan"大唐貞觀， referring to the Zhenguan era (626-49). Origin and date unknown. Private collection, UK Reproduced with permission.

These seem to be of local manufacture, however, and we have no examples of similarly shaped booklets of metropolitan quality suitable for inclusion in such a box as this. ${ }^{37}$

37 See Colin Chinnery, "Bookbinding," downloadable from the website of the International Dunhuang Project (http://idp.bl.uk/ downloads/Bookbinding.pdf). 


\begin{tabular}{|c|c|c|c|c|}
\hline $\begin{array}{l}\text { Origin and/or } \\
\text { location }\end{array}$ & Text & $\begin{array}{l}\text { Material and } \\
\text { technique }\end{array}$ & Measurements & Date \\
\hline $\begin{array}{l}\text { White Pagoda, } \\
\text { northeast China }\end{array}$ & $\begin{array}{l}\text { Sutra of the Dhārānì of } \\
\text { Pure Unsullied Light } \\
\text { (extract?) }\end{array}$ & Gilt silver; inscribed & $11.6 \times 21.2 ;$ one plate & No later than 1049 \\
\hline $\begin{array}{l}\text { White Pagoda, } \\
\text { northeast China }\end{array}$ & $\begin{array}{l}\text { Sutra of the Dhārānī of } \\
\text { Pure Unsullied Light }\end{array}$ & Gilt silver; inscribed & $\begin{array}{l}9.0 \times 102.5 ; \text { one long } \\
\text { plate }\end{array}$ & No later than 1049 \\
\hline $\begin{array}{l}\text { North Pagoda, } \\
\text { Chaoyang, Liaoning }\end{array}$ & Heart Sutra & Silver; unknown & $11.3 \times 362.2$ & No later than 1043 \\
\hline $\begin{array}{l}\text { Korea (private } \\
\text { collection) }\end{array}$ & Thousand-arm Sutra & Gold; inscribed & $\begin{array}{l}11.1 \times 12.8 \text {; sixteen } \\
\text { hinged gold plates }\end{array}$ & $\begin{array}{l}\text { Koryŏ dynasty } \\
(918-1392)\end{array}$ \\
\hline $\begin{array}{l}\text { Korea (Zentner } \\
\text { Collection) }\end{array}$ & Heart Sutra & Gilt metal; repoussé & $\begin{array}{l}\text { Several plates said to } \\
\text { be } 22-24 \mathrm{~cm} \text { long }\end{array}$ & $\begin{array}{l}\text { Koryŏ dynasty } \\
(918-1392)\end{array}$ \\
\hline $\begin{array}{l}\text { Hasedera, Nara } \\
\text { Prefecture, Japan }\end{array}$ & Lotus Sutra (partial) & Copper; inscribed & $83.3 \times 75.0 ;$ one plate & $7^{\text {th }}$ century \\
\hline $\begin{array}{l}\text { Kunitama shrine, } \\
\text { Kyushu, Japan }\end{array}$ & $\begin{array}{l}\text { Lotus Sutra and Sutra of } \\
\text { the Heart of Wisdom }\end{array}$ & Copper; inscribed & $\begin{array}{l}21.0 \times 18.0 ; \text { thirty-three } \\
\text { plates }\end{array}$ & Heian period (794-1185) \\
\hline $\begin{array}{l}\text { Korea? (private } \\
\text { collection in UK) }\end{array}$ & $\begin{array}{l}\text { Sutra on the Divination } \\
\text { of the Effect of Good } \\
\text { and Evil Actions (incom- } \\
\text { plete) }\end{array}$ & Gilt metal; repoussé & $\begin{array}{l}18.6 \times 12.7 \text {; fourteen } \\
\text { plates paired to form } \\
\text { seven hinged plates }\end{array}$ & $10^{\text {th }}$ or $11^{\text {th }}$ century? \\
\hline $\begin{array}{l}\text { Korea? (private } \\
\text { collection in UK) }\end{array}$ & $\begin{array}{l}\text { Ji dasheng xiang jing } \\
\text { (incomplete) }\end{array}$ & Gilt metal; repoussé & $\begin{array}{l}18.6 \times 12.7 ; 14 \text { plates } \\
\text { paired to form seven } \\
\text { hinged plates }\end{array}$ & $10^{\text {th }}$ or $11^{\text {th }}$ century? \\
\hline
\end{tabular}

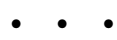

All the examples described above show that the production of Buddhist texts on gold, silver, and copper was widely practiced in East Asia as well as in parts of the Buddhist ecumene further to the west. There are two features that they have in common and others that they do not, and it is now time to turn our attention to these. For convenience the key data are laid out in table 1.

The first point that they have in common is that they were discovered as a result of archaeological excavation or of repairs to pagodas: in other words, these texts were not made for reading but rather were buried. The point of burying texts inscribed on gold or other metal plates might have been simply to preserve 
the texts for future generations. However, they appear to have more in common with the practices described earlier in which material texts constituted 'written embodiments of Buddhahood' that were then subjected to 'ritual burial' by being placed inside stupas. The connection between texts and their entombment in stupas is made explicit in the Sutra of the Dhärānī of Pure Unsullied light, and the practice of deliberately 'burying' texts, that is entombing them within stupas, goes back to the texts stamped on clay in the second century BCE, as mentioned at the beginning of this article. It can also be connected with at least some of the Gandhāran Buddhist texts written on birch bark, with much later birchbark manuscripts found in what is now Mongolia, and possibly with sutra burials in Heian-period Japan. The Japanese sutra burials, however, are not closely connected with stupas and were instead principally motivated by a desire both to ensure the survival of texts and to achieve personal religious goals. What is more, many of them were copies made on expensive paper rather than metal, so they should probably be excluded from further consideration in connection with metal texts. ${ }^{38}$

Tentatively, then, the production of Buddhist texts on gold, silver, and copper can be seen as an extension of the practice of the ritual burial of texts in stupas, with the difference that the use of precious metals was a means of doing the texts greater honor by writing them on precious materials, of preserving them in line with Ashoka's reported practice, and of symbolizing the economic and spiritual power of those who sponsored these practices. Nevertheless, it must be noted that some of the texts mentioned above are of unknown provenance (nos. 4, 5, and 7) and that some of the Japanese items described in no. 6 do not appear to have any direct connection with burial inside stupas. Consequently, we cannot state with confidence that these metal texts were all produced for ritual burial in stupas.

The second feature that they have in common is the

38 Ingo Strauch, "Looking into Water-Pots and over a Buddhist Scribe's Shoulder-On the Deposition and the Use of Manuscripts in Early Buddhism," Asiatsiche Studien Études Asiatiques 68 (2014): 797-830; Vesna A. Wallace, "Diverse Aspects of the Mongolian Buddhist Manuscript Culture and Realms of Its Influence," in Buddhist Manuscript Cultures: Knowledge, Ritual, and Art, eds. Stephen C. Berkwitz, Juliane Schober, and Claudia Brown (Abingdon: Routledge, 2009), 82; and John M. Rosenfield and Shūjirō Shimada, Traditions of Japanese Art: Selections from the Kimiko and John Powers Collection (Cambridge, MA: Fogg Art Museum, 1970), 56-61. use of precious metals, which applies to all the examples listed except those from Japan, which use copper. Some of them use solid gold or silver, while others are merely gilt. It is not clear how these differences are to be explained: are cost and the availability of precious metals the key factors? Alternatively, was gold chosen on account of its permanence and prestige? If permanence was a factor, why are so many of the texts incomplete or partial rather than complete sutras? Or again, was it a matter of texts on more precious materials being seen as more efficacious? In Mongolia it was considered that the more precious the material on which a Buddhist text was written the more efficacious it would be, and this may well reflect views current elsewhere in East Asia. ${ }^{39}$ It is probably partly for the same reason that some Buddhist manuscripts in East Asia were executed in gold ink on indigo-colored paper: both the gold ink and the indigo-dyed paper were expensive commodities, and while their use suggests 'aesthetic authority' and conspicuous consumption, the stronger motive was probably that of efficacy. ${ }^{40}$

One factor that these texts do not have in common is the choice of text. The ones from Japan consist mostly of the text of the Lotus Sutra, which so far has not been found elsewhere. Two of the Khitan texts from the White Pagoda come from the Sutra of the Dhärāni of Pure Unsullied Light, which, as we have shown, is closely connected to the practice of ritual burial of texts. The other texts so far found consist of the Sutra on the Divination of the Effect of Good and Evil Actions, the Diamond Sutra, the Thousand-arm Sutra, the Heart Sutra, and the Sutra of the Heart of Wisdom. Only some of these texts are connected to the apotropaic or ritual functions of texts, and with such a relatively small sample it is not clear what determined the choice of text. Nor is it clear why most of them are incomplete.

The second factor that they do not have in common is size. One is more than three meters in length, others are much smaller. Is this again merely a matter of cost and availability, or are other factors at work? At this stage it is too early to tell.

\footnotetext{
39 Wallace, "Diverse Aspects of the Mongolian Buddhist Manuscript Culture," 86.

40 Blair, Real and Imagined, 178; Charlotte Eubanks, Miracles of Book and Body: Buddhist Textual Culture and Medieval Japan (Berkeley: University of California Press, 2011), 142, 167; and Chang Ch'ung-sik, Han'guk sagyŏng yŏn'gu (Seoul: Tongguk taehakkyo ch'ulp'anbu, 2007).
} 
The final question to address here is how these metal texts were produced, for here, too, there are clear differences to be observed. In many of the cases described above, it is clear that the text has been incised into the surface of the metal using a stylus. This is definitely true of the copper plates from Kunitama shrine in Japan and the other items of Japanese origin. These, as we have seen, also differ from the other cases in terms of choice of text and material.

In some of the cases from Korea, however, it is clear that a different technique has been used to transfer a whole page of text onto the gold, silver, or copper plate. The technique used in these cases is known as repoussé, which is of considerable antiquity. The oldest textual example known appears to be MS 5236 in the Schøyen Collection in Norway. This is a gold amulet carrying an embossed text. For palaeographic and linguistic reasons it is tentatively assigned to the sixth century вСЕ and was produced either in Euboia or Asia Minor. ${ }^{41}$ Although some controversy surrounds this amulet, the consensus now is that it is genuine. What is important about it, apart from the technique used for its production, which must have been capable of producing multiple impressions on gold or other soft metals, is that it was not a text for reading but a text designed to fulfill an apotropaic or ritual function, as were the Indian Buddhist clay sealings, some of the Sumerian clay impressions, and of course the dhäraṇi printed on paper in Japan and Korea.

The repoussé technique was certainly capable of producing a whole page of text at once, but exactly how it was done in each case is unclear. There are perhaps two possibilities: one is to carve a wooden block with the text in intaglio and reversed, and then press the gold leaf into the indented text, but this would not be possible in the case of gilt-silver or thicker metal plates.

\footnotetext{
41 The amulet is shown and described at http://www.schoyencollection.com/pre-gutenberg-printing/21-1-blind-on-clay-gold/ms5236-gold-invocation-apollo (accessed 19 June 2016). At http:// epub.uni-regensburg.de/16319/ (accessed 19 June 2016) can be found further images and two unpublished studies: Herbert E. Brekle, "Analyse der Herstellungstechnik der Inschrift auf einem Goldamulett in der Schoyen Collection (London/Oslo)" (unpublished report, University of Regensburg, August 2010), and Dominic Montserrat, "Report on Early Greek Gold Lamella" (n.d.), which are discussed in Roland Cuthbert, The Esoteric Codex: Amulets and Talismans ([S.I.]: Lulu Press, 2015), 15-7. The only thorough study, however, is Giovanna Rocca, "Una lamina aurea dalla Collezione Schøyen (MS 5236)," Alexandreia/Alessandria: Rivista di glottologia 8 (2014): 125-36.
}

The other is to carve a wooden block with the text in relief and not reversed, and then press the gold leaf or other metal plate over it so that the text in relief is transferred to the metal. Whether this is in fact how these examples were produced is now impossible to know. However, some form of pattern or mold would be necessary in order to transfer a whole page of text at once, and this would have at least the potential of producing multiple copies, whether or not it was in fact used to do so. Given the fact that so far in no case have two 'imprints' from the same pattern or mold come to light, we cannot be sure that multiple copies were ever produced from them.

It is unfortunate that few of the items carry a date or can be dated securely, for if wooden blocks were prepared for repoussé work in the seventh century it would be surprising if they were not also used for printing on paper. This may be a good reason for being cautious about the dating of all the items that have so far come to light, but the item in the Schøyen Collection might, on the other hand, reasonably suggest that repoussé texts do not necessarily generate the idea of printing on other surfaces.

Further, it is not clear what might have determined the choice made between stylus incision and repoussé imprints. Given that precious metals were being used, it is difficult to suppose that the repoussé technique was chosen for the purpose of producing multiple copies. That being so, why take the trouble to prepare the pattern or mold just to produce one or a handful of copies? Was repoussé technology preferable for religious or some other reasons? Finally, of the two items that have so far come to light from the territory of the former Khitan empire, one is inscribed and no images seem to be available of the other, from the North Pagoda in Chaoyang, so it is not known if this was inscribed or not. Consequently, all the available repoussé imprints appear to be of Korean origin. Was this technique, then, practiced only in Korea, and why does it seem not have been used in Japan?

It will be obvious to readers of this article that the examples from East Asia discussed here vary considerably in terms of text, material, technology, and date. Does that invalidate the attempt made here to treat them as part of one and the same phenomenon? In our view it does not, and that is for three reasons: because they all reproduce texts from the Chinese Buddhist canon; because other texts in the Chinese Buddhist canon mention these practices and thus conveyed them 
to Japan, the Khitan empire, the Korean states, and Vietnam; and because of the association with stupas in all cases where the provenance is known. With regard to the third point, however, it is clear that the Japanese examples do not fit the pattern. Since in other respects, too, they differ from the continental examples, it would probably be appropriate to consider them as a separate phenomenon. ${ }^{42}$ The other East Asian examples clearly have points in common not only with each other but also with similar practices in South and Southeast Asia. The most likely hypothesis is that the preparation and burial of Buddhist texts on precious metals is a practice that was transmitted to China from South and/or Southeast Asia and then further to the Khitan empire and the Korean peninsula, but this remains no more than a hypothesis.

The problem with the continental East Asian examples is partly that we do not have consistent information about all of them, and also that the number of samples is still small. In fact, apart from the Japanese sutra burials, all the East Asian examples discussed in this article have come to light only in the last sixty years, and some much more recently than that. We must therefore await further discoveries in order to increase the size of the sample pool and then determine their common characteristics. At this stage, however, since most of the artifacts discussed in this article have hitherto been studied only in isolation, if at all, and since, what is more, the method of production has hitherto attracted no discernible interest, it has seemed to us worthwhile to present a preliminary account of these geographically dispersed and chronologically diverse artifacts with a discussion of the probable motives for their production and of the techniques used to produce them. If this article stimulates further research on them it will have achieved its aims.

\section{Bibliography}

Apple, James B. “The Phrase Dharmaparyāyo Hastagato in Mahāyāna Buddhist Literature: Rethinking the Cult of the Book in Middle Period Indian Mahāyāna Buddhism."

42 Moerman argues that Japanese sutra burials are without parallel in Buddhist Asia, and if this is indeed so then they are perhaps best treated as a different, albeit related, phenomenon. Moerman, "The Death of the Dharma," 71-2.
Journal of the American Oriental Society 134 (2014) 25-50.

Baba, Norihisa. "Sri Lankan Impacts on East Asian Buddhism: Transmission of a Dhāranī Sūtra." In Buddhism Without Borders: Proceedings of the International Conference on Global Buddhism. Edited by Dasho Karma Ura and Dendup Chophel, 257-67. Bhutan: The Centre for Bhutan Studies, 2012. http://www.bhutanstudies.org.bt/ category/conference-proceedings/. Accessed 1 September 2016.

Barrett, T. H. "Did I-Ching Go to India? Problems in Using I-Ching as a Source on South Asian Buddhism." Buddhist Studies Review 15 (1998): 142-56.

The Woman Who Discovered Printing. New Haven: Yale University Press, 2008.

Beal, Samuel. Si-yu-ki. Buddhist Records of the Western World. 2 vols. London: Kegan Paul, Trench, Trübner \& Co., 1906.

Bentor, Yael. "On the Indian Origins of the Tibetan Practice of Depositing Relics and Dhâranîs in Stūpas and Images." Journal of the American Oriental Society 115 (1995): 248-61.

Blair, Heather. Real and Imagined: The Peak of Gold in Heian Japan. Cambridge, MA: Harvard University Asia Center, 2015.

Bokenkamp, Stephen R. Early Daoist Scriptures. Berkeley: University of California Press, 1997.

Brekle, Herbert. "Analyse der Herstellungstechnik der Inschrift auf einem Goldamulett in der Schoyen Collection (London/Oslo)". Unpublished report, University of Regensburg, August 2010. http://epub.uni-regensburg. de/16319/. Accessed 19 June 2016.

Chang Ch'ung-sik 張忠植. Han'guk sagyŏng yŏn'gu 한국 사 경 연구. Seoul: Tongguk taehakkyo ch'ulp'anbu, 2007.

Cheng, Chuan. "Designations of Ancient Sri Lankan Buddhism in the Chinese Tripitaka." Journal of the Oxford Centre for Buddhist Studies 2 (2012): 104-23.

Chinnery, Colin. "Bookbinding." http://idp.bl.uk/downloads/Bookbinding.pdf. Accessed 1 September 2016.

Collon, Dominique. First Impressions: Cylinder Seals in the Ancient Near East. London: British Museum, 1987.

Copp, Paul. "Altar, Amulet, Icon: Transformations in Dhāraṇī Amulet Culture, 740-980." Cahiers d'Extrême-Asie 17 (2008): 239-64.

Cuthbert, Roland. The Esoteric Codex: Amulets and Talismans. [S.1.]: Lulu Press, 2015.

Dong Gao 董高 and Zhang Hongbo 张洪波. “Liaoning Chaoyang beita tiangong digong qingli jianbao 辽宁朝阳 北塔天宫地宫清理简报.” Wenwu 文物 434 (1992.7): 6. 
Drewes, David. "Revisiting the Phrase 'Sa Prthivīpradeśaś Caityabhüto Bhavet' and the Mahāyāna Cult of the Book." Indo-Iranian Journal 50 (2007): 101-43.

Eubanks, Charlotte. Miracles of Book and Body: Buddhist Textual Culture and Medieval Japan. Berkeley: University of California Press, 2011.

Falk, Harry. "Die Goldblätter aus Śrī Kșetra." Wiener Zeitschrift für die Kunde Südasiens 41 (1997): 53-92.

Foshuo pusa xing fangbian jingjie shentong bianhua jing 佛 説菩薩行方便境界神通變化經. To9no271_po315c290316ao1 (CBETA digitized canon).

Foshuo wunengsheng damingwang tuoluonijing 佛説無能勝 大明王陀羅尼經T21n1233 (CBETA digitized canon).

Fozu tongji 佛祖統紀, T49n2035 (CBETA digitized canon). Griffiths, Arlo. "Early Indic Inscriptions of Southeast Asia." In Lost Kingdoms: Hindu-Buddhist Sculpture of Early Southeast Asia. Edited by John Guy, 53-7. New York: Metropolitan Museum of Art, 2014.

"The 'Greatly Ferocious' Spell (Mahāraudra-nāma-hrdaya). A Dhäranī Inscribed on a Lead-bronze Foil Unearthed near Borobudur." In Epigraphic Evidence in the Pre-modern Buddhist World. Edited by Kurt Tropper, 1-36. Vienna: Arbeitskreis für Tibetische und Buddhistische Studien, Universiät Wien, 2014.

"Written Traces of the Buddhist Past: Mantras and Dhāran̄is in Indonesian Inscriptions." Bulletin of the School of Oriental and African Studies 77 (2014): 137-94.

. "New Documents for the Early History of Punḍravardhana: Copperplate Inscriptions from the Late Gupta and Early post-Gupta Periods." Pratna samiksha 6 (2015): 15-38.

Griffiths, Arlo and D. Christian Lammerts. "Epigraphy: Southeast Asia." In Brill's Encyclopedia of Buddhism. Edited by Jonathan A. Silk, vol. 1, 988-1009. Leiden: Brill, 2015.

Holt, John Clifford. Buddha in the Crown: Avalokiteśvara in the Buddhist Traditions of Sri Lanka. Oxford: Oxford University Press, 1991.

Institut de philosophie orientale and Association culturelle Soka de France, eds. Sūtras bouddhiques: un héritage spirituel universel. Manuscrits et iconographie du Sūtra du Lotus. Paris: Les Indes savants, 2016.

Ishida Mosaku 石田茂作. “Wagakuni hakken no dōbankyō ni tsuite 我國發見の銅板經に就いて”. In Ishida Mosaku, Bukkyō kōkogaku ronkō 佛教考古學論改, vol. 3, 377-408. Kyoto: Shibunkaku Shuppan, 1977.

Jayasuriya, M. H. F. The Jetavanārāma Gold Plates: Being a Fragmentary Sri Lankan Recension of the Pañcav- iṃśatisāhasrikā Prajñāpāramitā Sūtra. [Kelaniya:] University of Kelaniya, [1988].

Karashima, Seishi. A Critical Edition of Lokaksema's Translation of the Aștasāhasrikā Prajñāpāramitā 道行般若 經校注. Tokyo: The International Research Institute for Advanced Buddhology, Soka University, 2011.

Kataoka Naoki 片岡直樹. “Hasedera dōban Hokke sessōzu no meibun ni tsuite: Kōtei, kaishaku chōkokugihō 長谷 寺銅板法華説相図の銘文について 校訂・解䣋 · 彫 刻技法." Niigata Sangyō Daigaku Keizaigakubu kiyō 新潟 産業大学経済学部紀要 40 (2012): 1-17.

Kim, Youn-mi. "The Hidden Link: Tracing Liao Buddhism in Shingon Ritual." Journal of Song-Yuan Studies 43 (2013): 117-170.

Kornicki, Peter. "The Hyakumantō Darani and the Origins of Printing in Eighth-Century Japan." International Journal of Asian Studies 9 (2012): 1-28.

Lai, Whalen. "The Chan-cha ching: Religion and Magic in Medieval China." In Chinese Buddhist Apocrypha. Edited by Robert Buswell, 175-206. Honolulu: University of Hawai'i Press, 1990.

Lawson, Simon D. "A Catalogue of Indian Buddhist Clay Sealings in British Museums." Unpublished D.Phil. dissertation, University of Oxford, 1982.

Ledderose, Lothar. Ten Thousand Things: Module and Mass Production in Chinese Art. Princeton, NJ: Princeton University Press, 2000.

Litvinskii, B. A. and T. I. Zeimal. "Nekotorye aspekty ierarkhii i semantiki stūpa b srednei Azii i Indii." In Drevniaia Indiia: istoriko-kul'turnye sviazy. Edited by G. M. Bongard-Levin, 164-86. Moscow: Nauka, 1982.

Losty, Jeremiah P. The Art of the Book in India. London: British Library, 1982.

Lwin, Thein, Win Kyaing, and Janice Stargardt. "The Pyu Civilization of Myanmar and the City of Śrī Kṣetra.” In Lost Kingdoms: Hindu-Buddhist Sculpture of Early Southeast Asia. Edited by John Guy, 63-8. New York: Metropolitan Museum of Art, 2014.

Ma, Chengyuan. "The Splendor of Ancient Chinese Bronzes." In The Great Bronze Age of China: An Exhibition from the People's Republic of China. Edited by Wen Fong, 1-19. New York: The Metropolitan Museum of Art, 1980.

McBride, Richard D. "Dhāraṇī and Spells in Medieval Sinitic Buddhism." Journal of the International Association of Buddhist Studies 28 (2005): 85-114.

Makita Tairyō 牧田諦亮. Rikuchō koitsu Kanzeon ōgenki no $k e n k y \bar{u}$ 六朝古逸觀世音應驗記の研究. Kyoto: Heirakuji Shoten, 1970. 
Moerman, D. Max. "The Death of the Dharma: Buddhist Sutra Burials in Early Medieval Japan." In The Death of Sacred Texts: Ritual Disposal and Renovation of Texts in World Religions. Edited by Kristina Myrvold, 71-90. Farnham: Ashgate, 2010.

Montserrat, Dominic. "Report on Early Greek Gold Lamella.” (n.d.). http://epub.uni-regensburg.de/16319/. Accessed 19 June 2016.

Neimenggu Balin youqi bowuguan 内蒙古巴林右旗博物 館. “Liaodai shijia fo shelita nei chutu de Wugou jingguang ta tuoluoni jing liu jin yin ban 辽代释迦佛舎利塔 内出土的 “无垢浄光大陀罗尼经” 嘘金银板.” Beifang wenwu 北方文物 69 (2002): 52-3.

Ratnayaka, Hema, M. H. Sirisoma, and Siri Heenpella. Jetavanārāma Gold Plates. Colombo: Ministry of Cultural Affairs, 1983.

Raz, Gil. The Emergence of Daoism: Creation of a Tradition. Abingdon: Routledge, 2012.

Rocca, Giovanna. "Una lamina aurea dalla Collezione Schøyen (MS 5236)." Alexandreia/Alessandria: Rivista di glottologia 8 (2014): 125-36.

Rosenfield, John M. and Shūjirō Shimada. Traditions of Japanese Art: Selections from the Kimiko and John Powers Collection. Cambridge, MA: Fogg Art Museum, 1970.

Salomon, Richard. Indian Epigraphy: A Guide to the Study of Inscriptions in Sanskrit, Prakrit, and the Other Indo-Aryan Languages. Oxford: Oxford University Press, 1998.

Shen, Hsueh-man, ed. Gilded Splendor: Treasures of China's Liao Empire (907-1125). New York: Asia Society, 2006.

Silk, Jonathan. "Canonicity." In Brill's Encyclopedia of Buddhism. Edited by Jonathan A. Silk, vol. 1, 5-37. Leiden: Brill, 2015.

Song Ilgi 宋日基. “Iksan Wanggungt’ap Kŭmji kŭmgang sagyŏng ŭi munhŏnhakjŏk chŏpkŭn 益山王宮塔『金紙 金剛冩經』의 文獻學的接近.” Sŏjihak yŏngu 24 (2002): 131-59.

. "Kyŏngdo Ch’ŏngnyŏnwŏn chang Kwanseŭm ŭnghŏmgi sosu Paekche kisa ŭi kyŏndo 京都靑蓮院藏「觀 世音應驗記」所收 百濟記事 의 檢討.” Sŏjihak yŏngu 30 (2005): 129-49.

Stargardt, Janice. "The Oldest Known Pali Texts, 5th-6th Century; Results of the Cambridge symposium on the Pyu Golden Pali Text from Srī Kṣetra, 18-19 April 1995." Journal of the Pali Text Society 21 (1995): 199-213.

Strauch, Ingo. "Looking into Water-pots and over a Buddhist Scribe's Shoulder-On the Deposition and the Use of Manuscripts in Early Buddhism." Asiatsiche Studien Études Asiatiques 68 (2014): 797-830.
Taguchi Eiichi 田口栄一. “Dōban Hokkekyō, tsuketaru dōbakoita 銅板法華経・付銅管板.” Kokka 国華 957 (1973): 44-53.

Takakusu, Junjiro. A Record of the Buddhist Religion as Practised in India and the Malay Archipelago (A.D. 671-695). Oxford: Clarendon Press, 1896.

Teishitsu Hakubutsukan 帝室博物館, ed. Kinpusen kyōzuka ibutsu no kenkyū 金峯山経塚遺物の研究. Tokyo: Tōkyōdō Shuppan, 1979 (facsimile of 1937 edition).

Tuladhar-Douglas, Will. "Writing and the Rise of Mahāyāna Buddhism." In Die Textualisierung der Religion. Edited by Joachim Schaper, 250-72. Tübingen: Mohr Siebeck, 2009.

Wallace, Vesna A. "Diverse Aspects of the Mongolian Buddhist Manuscript Culture and Realms of Its Influence." In Buddhist Manuscript Cultures: Knowledge, Ritual, and Art. Edited by Stephen C. Berkwitz, Juliane Schober, and Claudia Brown, 76-94. Abingdon: Routledge, 2009.

Yajima Kyōsuke 矢島恭介. "Kinpusen shutsudo no dōbankyō 金峯山出土の銅板経.” Yamato bunka kenkyū 大和文化研究 4, no. 3 (1957): 1-16.

Yi Chaejun 李在俊. “Kŭmje Chŏnsugyŏng e kwanhan sogo 金製 千手經에 관한小考.” Munhwasahak 21 (2004): 519-36. 